\title{
Literature And Libration in Africa: An Appraisal of Ngugi Wa Thiogo's A Grain of Wheat
}

\author{
Assoh Bernard Bem \\ Department of English and French, Police Academy Kano, Nigeria
}

Received: 06-08-2014

doi:10.7575/aiac.ijclts.v.2n.4p.27
Accepted: 22-09- 2014

Published: 01-10- 2014

\begin{abstract}
The present study captures the role of the literary artists in the struggle for emancipation of Africa. Brief allusions are made to southern and western African literary works, but East Africa is used as a major microcosm of the representation. Ngugi wa Thiongo's A Grain of Wheat (1967) is analyzed using the sociological approach to the study of literature with a view to identifying how the author has through the instrumentality of his novel been able to project the realities of blacks emancipation in Kenya. To this end therefore, the historical, economic and social realities of the Kenyan society is analyzed as source materials which Nguigi has used to x-ray his society. The research concludes that, Ngugi has been able to effectively capture the realities of his society through his novel.
\end{abstract}

Keywords: Microcosm, Sociological, Instrumentality, Economical

\section{Introduction}

Ngugi Wa Thiongo', currently distinguish Professor of English and comparative literature and Director of the international centre for writing and translation at the University of California, Irvine, was born on January $5^{\text {th }} 1938$ into a large Peasant Family. He was educated at Kamandura, manguu and Kinyogdori Primary schools. Alliance High School, all in Kenya, Makerere University college (then campus of London University), Kampala Uganda, and the University of Leeds, Britain. He is a recipient of seven honorary member of the American Academy of letters. A many sided intellectual, he is a novelist, essayist, playwright, journalist, editor, and academic and social activist.

The Kenyan of his birth and Youth was a British settler colony (1895 - 1963). As an adolescent, he lived through the Mau Mau War of Independence (1952 - 1962), the central historic episode in making of modern Kenya and a major theme in A Grain of Wheat. Thus, A Grain of Wheat (1967) was a turning point in the formal and ideological direction of his works. His development as an artist and intellectual has paralleled and played a large part in the development of the writing and thinking of the post and Neo-colonial world away from the constraining influence of western culture towards the recovery, expression, and in some ways creation of native culture.

The sociological approach to the study of literature views a work on the premise of its social determinants. These social determinant could be political, economic, religious, culture among others, this approach exists against the fact that literature of a people reflects essentially the realities of such society and as such both literature and society are influenced by each other writers influenced of sociological approach write to either propagate an economic or social change, teach moral values or promote culture beliefs. In doing so, the historical trait of such society is not left in isolation. The sociological theory is largely influence by Marxist and feminist theories of literary criticism. This informs while Ngugi returning to his native land and studying Marxist writes and work of liberationist thinkers such as Frantz Fanon, confronted the problem faced by the newly independent Nations, and the struggle for the establishment of a national culture against the continued legacy of post colonial compromise and corruption.

These efforts include the abolishment of the department of English at the University of Nairobi and the establishment of a Department of literature devoted to studying the literature of Africans and its Diaspora Africa and the third world. They also included the dropping of his Christian first name in recognition of the church's implication in colonialism (Skutsch ,2013:2).

The sociological approach, therefore, places emphasis on the writer as a social crusader and mobilizer and in doing so does it accurately with the historical values of the society from which his themes emanate.

\section{Sociological Analysis}

Ngugi Wa Thongo's A Grain of Wheat is built solely on the political, economic and social realities of his people of Kenya. The novel therefore, draws its theme from the reality of the situation on ground which Durden capture in interview conducted with Ngugi thus: 
The land issue forms a major crux of Ngugi concern. The novel is generally been looked upon as a political novel portraying the difficulties or otherwise of Kenya's independence struggle, the often time betrayer and disillushment that followed the struggle forms the crux of the social responsibility of Ngugi's A Grain Wheat.(Durden, 1978: 123)

Ngugi therefore, classified people who fought for independence those who fought with all might to attain independence that took the oath and were ready to stand by it and course those who opposed its way of compromising both their stand and the oath they had taken. Karanja driven by his selfish love for a woman comprises his oath by his love to Mumbi, inspite of his knowledge about her relationship with Gikonyo who was in detention. The height of the betrayal comes with karanja not just coming to denounce his oath by joining the home guard "I could not believe it. He had been a friend of Kihika and Gikonyo; they had taken the oath together; how could he betray them? (Ngugi 125).In doing so, Ngugi intends to expose as well as praise the character and brevity of kihika the protagonist in the novel and the attendant betrayer he got from Gikonyo:

He led other home into the forest to hunt down freedom fighters. It was also during his ruling that even the few remaining fit men were taken from the village to detentions camps. He become very strict with curfew laws and forced communal work (Ngugi 129).

A Grain of Wheat is not so much novel of protest as of vindication. Ngugi sets out to dispel the myth fostered by the colonial rurals that the "Mau-mau is simply and purely evil". The basic objectives of the man-man revolutionaries is to drive out the Europeans, seize the government, and give back to Kenya peasants their stolen land and property. Kihika, Mugo, Gikonyo, Mumbi, Wurui, and Wanbai, stand out in the novel but Kihika's vision of an independent Kenya is moved by the story of Moses and the children of Israel, and like the prophet, he hopes to lead his people to the promise land, which thus becomes his is social responsibility.

It is again difficult to analyze Ngugi's $A$ Grain of Wheat, without taken into account the Christian myths which do not only constitute the basic frame of the story and incorporates the author's message but also dominates his use of images and symbols. All the leading characters in the novel make use of Christian concepts to express their dreams and aspiration. Mumbi often equated herself with Esther in the Bible.

In the Old Testament she often saw herself as Esther: so she revealed in that movement when Esther, finally answer king Ahasuesra's question and dramatically point at Haman, saying: The adversary and enemy is the wicked Haman (Ngugi 67).

Similarly, Ngugi leaves little doubt abouth his likeness for Kihika who he believes is the true Christ who, through sacrifices, not justifies himself but also brings about in the lives of his friends and followers by showing them the way of spiritual regeneration. The title of the novel is drawn from a verse in the Bible "Verily, verily I say to you, except a corn of wheat fall into the ground and die, it abideth alone; but if it die it bringeth forth fruit" (St. John 12:24). This verse becomes the guiding principle in the life and actions of Kihika as he underlines it in black in his personal Bible. Kihika emphasizes this zeal spurred by his belief in this verse when he says "what we want in Kenya are men and woman who will not run away before the sword" (Ngugi 78).

The activities of the Mau-man draw Kihika into public limelight. The secret betrayer of Kihika becomes a "public strength as the social needs and social acceptance becomes all that is required for Leadership, (Edgar 96). On the surface Mumbi's story is that of an attractive young bride caught in the event of the emergence as she struggle to remain independent and untouched, motivated by the love for her husband. She is however, tempted by Karanja, and in the bid for survival she eventually falls for Karanja who manifest his unwanted affection through gifts of food. When Mumbi learns of Gikonyo's return she inexplicably gives herself to Karanja; later she gives birth to child a situation Gikonyo cannot accept on his return.

The reality of post colonial Kenya's state is presented by Ngugi with despair. The value system of the society has been given off for affluence by the blacks who have taken over the mantle of leadership from the white little or no regard is given to the people who laid down their lives sin the struggle for independence. Nationalism has given way to capitalism. This is presented in a speech by one of the core independent fighters Gikonyo when he says;

But now, whom do we see riding in long cars and changing then daily as motor cars were clothes? It is those who did not take part in the movement, the same who ran to the shelter of school and universities and administration. At political meetings you hear then shout: Uhuru, Uhuru we fought for. Fought where? They are mere uncircumcised boys. They knew suffering as a word (Ngugi 60).

This loss of hope which has enveloped the newly independent Kenyan society goes to reflect the reality of the situation as it were. Here Ngugi once again meets the core of the sociological theory which Shija captures as "Fight for social and economic change where the need arises. It also prescribe that artist should interpret society in a way that could show its historical movement and social dynamics"' (Shija 2006:14).

The bound between Marxism and the sociological theory in literary criticism cannot be over emphasized. Marxism provides material which literature uses to explore the socioeconomic life of people. Marxist literature creates awareness that motivate the masses to revolt against the bourgeois. This revolt sometime involves violence and bloodshed. Ngugi in emphasizing this idea makes an illusion to the person and situation in India before its independence. "The example of India is here before our noses. The British were there for hundred and hundred years. They eat India' wealth (Ngugi 77). 
The violent freedom championed by Gandhi is explore to show how he alone was able to stimulate his people to revolt through unity and self sacrifice.

They sent Gandhi to prison, not once, but many time. The stone wall of prison could not hold him. Thousands were jailed thousand more were killed. Men and women and children threw themselves in front of moving train and were run over. Blood flow like water in that country. The bomb could not kill the blood, red blood of people, crying out to be free (Ngugi 77).

Bloodshed is here emphasized as not been just the means of achieving freedom but a sure way to most independent struggles. The general tone in A Grain Of Wheat is one of bitterness and anger. Painful memories of the mau-mau violence still overhang the Kikuyu villages, as the attainment of independence fails to bring the cherished social dreams. The celebration of Uhuru break up in confusion and disappointment. Shatto captures it thus;
All the events in the novel have been directly or indirectly related to the struggle for independence and therefore, understandably, the celebrations of the events becomes the symbolic focus of the peoples aspiration and social dreams... thus by carefully structuring the novel around this momentous event in the history of the nation the author is able to high-light the illusion which tend to be fostered by the euphoric atmosphere of independences (Shatto 109).

The novel captures issues association with historical novels by way of the thematic pre-occupation of the novel revolving round the issues of the mau-mau wars. Ngugis disenchantment with the realities of his cotemporary environment has influenced the basis of his thematic concerns. The essence of his writing is therefore, built on the social conditions of his people and the overall zeal to capture reality via creativity. The determination for an independent Kenya is seen as the only success that will be recorded. The coming of freedom is therefore, viewed with enthusiasm and happiness. Ngugi further reaffirms it thus;

Kenya regained her Uhuru from the British on the 12 December 1963. A minute before midnight, lights were put out at the Nairobi stadium so that people from all over the country and the world who had gathered there for the midnight ceremony were swallowed by the darkness. In the dark, the union jack was quickly lowered. When next the light came on the the new Kenya flag was flying and fluthering, and waving, in the air. The police band played the new National anthem and the crowd cheered continuously when they saw the flag was black, and red and green (Ngugi 177).

Freedom here is greeted with zeal and enthusiasm. Ngugi has combined his role as a teacher and freedom fighter to reflect the difficulties that were associated with the struggle for independence. The betrayers, the Sabbotaurs and the unified efforts that characterized these struggles are also itemized and discussed. His concerns have been that of libration and emancipation of his people.

\section{Conclusion}

From the foregoing, therefore, Ngugi Wa Thiongo's A Grain of Wheat has not just explored the historical realities of the colonial and early independent Kenyan a society, but has also exposed the social and economic life as it were, alongside the realities of the mau-mau wars. In doing so, Ngugi has not just only drawn his source material from his immediate environment but has also used such material to actualize his aim of combining both history and fiction to present the reality of the British settler colony of Kenya and also contributing to knowledge in this regard.

\section{References}

Skutsch, C. 2013). "Ngugi Wa Thiongo ". <httap://web.missiouri.edu/cohenss/ngugi>

Durden ,D. and Pieterse, C.(ed.).(1978). African Writer Talking.Heinemann, Press.

Howard, W. J.(ed.).(1982). "Themes and Development in the Novels of Ngugi." The critical Evaluation of African Literature. Edger Wright. London: Heinemann, press.

Thiongo, N. W. 1980). A Grain of Wheat. London: Heinemann, Press.

Shatto G. (1982). The novel and contemporary experience in Africa. London, Heinamann Press.

Shija, T. (2006). Postcolonialism and the poetry of Tanure Ojaide. Makurdi: A boki Publihees. 